\title{
Blood-Based Biomarkers Are Associated with Different Ischemic Stroke Mechanisms and Enable Rapid Classification between Cardioembolic and Atherosclerosis Etiologies
}

\author{
Dorin Harpaz ${ }^{1,2, *}$, Raymond C. S. Seet ${ }^{3}$, Robert S. Marks ${ }^{2} \mathbb{D}$ and Alfred I. Y. Tok ${ }^{1}$ (D) \\ 1 School of Material Science \& Engineering, Nanyang Technology University, 50 Nanyang Avenue, \\ Singapore 639798, Singapore; miytok@ntu.edu.sg \\ 2 Department of Biotechnology Engineering, Ben-Gurion University of the Negev, Beer-Sheva 84105, Israel; \\ rsmarks@bgu.ac.il \\ 3 Division of Neurology, Department of Medicine, Yong Loo Lin School of Medicine, National University of \\ Singapore, NUHS Tower Block, 1E Kent Ridge Road, Singapore 119228, Singapore; mdcrscs@nus.edu.sg \\ * Correspondence: dorin001@e.ntu.edu.sg or dorinha@post.bgu.ac.il or harpaz.dorin@gmail.com
}

Received: 22 September 2020; Accepted: 7 October 2020; Published: 9 October 2020

check for updates

\begin{abstract}
Stroke is a top leading cause of death, which occurs due to interference in the blood flow of the brain. Ischemic stroke (blockage) accounts for most cases (87\%) and is further subtyped into cardioembolic, atherosclerosis, lacunar, other causes, and cryptogenic strokes. The main value of subtyping ischemic stroke patients is for a better therapeutic decision-making process. The current classification methods are complex and time-consuming (hours to days). Specific blood-based biomarker measurements have promising potential to improve ischemic stroke mechanism classification. Over the past decades, the hypothesis that different blood-based biomarkers are associated with different ischemic stroke mechanisms is increasingly investigated. This review presents the recent studies that investigated blood-based biomarker characteristics differentiation between ischemic stroke mechanisms. Different blood-based biomarkers are specifically discussed (b-type natriuretic peptide, d-dimer, c-reactive protein, tumor necrosis factor- $\alpha$, interleukin-6, interleukin- $1 \beta$, neutrophil-lymphocyte ratio, total cholesterol, triglycerides, low-density lipoprotein, high-density lipoprotein and apolipoprotein A), as well as the different cut-off values that may be useful in specific classifications for cardioembolic and atherosclerosis etiologies. Lastly, the structure of a point-of-care biosensor device is presented, as a measuring tool on-site. The information presented in this review will hopefully contribute to the major efforts to improve the care for stroke patients.
\end{abstract}

Keywords: ischemic stroke mechanisms; diagnostics; etiology classification; blood-based biomarkers; statistical analysis; point-of-care biosensors

\section{Introduction}

Stroke is a top leading cause of death, which occurs due to interference in the brain blood flow [1]. This interference is either due to ischemic stroke (blockage) in $87 \%$ of cases or due to hemorrhagic stroke (bleeding) in the remaining $13 \%$ of cases [2]. Ischemic stroke accounts for the majority of stroke cases, which makes ischemic stroke mechanism classification the second most important classification in stroke care [3]. There are four main ischemic stroke etiologies: $20 \%$ cardioembolic, $20 \%$ atherosclerosis (large artery disease), 25\% lacunar (small vessel disease) and 5\% other causes [4]. Additionally, $30 \%$ are termed cryptogenic strokes, which includes strokes from unknown causes $[5,6]$. The main value of subtyping ischemic stroke patients is for a better therapeutic decision-making 
process and to minimize time-to-thrombosis with the treatment of intervenors tissue plasminogen activator (IV-tPA) [4]. The average time is $3 \mathrm{~h}$ from stroke symptoms, and it was found useful only when administered within $4.5 \mathrm{~h}[7,8]$. Anticoagulant therapy is the optimal treatment for cardioembolic stroke, while atherosclerosis stroke and other non-embolic etiologies are recommended to follow antiplatelet therapy [9]. A need to detect cardioembolic stroke patients still exists, which would benefit from anticoagulation treatment [10]. Brain cells die rapidly after stroke; therefore, treatment needs to be administered rapidly. "Time is brain" [11-14] because diagnostic time delays are associated with the worsened outcome of patients [15-17]. Stroke is more common in the elderly population (>65 years) [18-21], and has multiple reported risk factors including dyslipidaemia, hypertension, diabetes, obesity, dietary factors, inactive lifestyle, smoking and alcohol consumption [22,23]. Previous studies [24-26] have reported several differences between ischemic stroke etiologies. It was found that: (1) cardioembolic stroke is common in the elderly ( $>70$ years), shows a smaller rate of secondary stroke, higher use of IV-tPA treatment, and the highest stroke severity; (2) atherosclerosis stroke is the most frequent stroke etiology in middle-aged patients (45-70 years), shows the highest rate of secondary stroke, the highest percentage of smoking, previous transient ischemic attack (TIA) and alcohol consumption; (3) lacunar stroke shows the highest rate of hypercholesterolemia, obesity, hypertension, diabetes mellitus and was associated with the lowest mortality and stroke severity. Since its development in 1993, the gold standard classification method for ischemic stroke etiologies is the Trial of Org 10172 in Acute Stroke Treatment (TOAST) classification [27-30]. It is mainly based on clinical symptoms and its reliability has been improved by the use of a computerized algorithm; however, the TOAST undetermined group is heterogonous because once a patient matches more than one possible etiology he is equally grouped as a patient with a no-cause identified or an incomplete investigation. Two additional classifications that are highly used including the National Institute of Neurological Disorders and Stroke (NINDS, Bethesda, MD, USA) classification [31] and The Oxford Community Stroke Project (OCSP) classification [32,33]. However, the current ischemic stroke mechanism classification methods are complex, time-consuming (between hours to days), and require professional personnel.

Specific blood-based biomarker measurements have promising potential to improve ischemic stroke mechanisms classification [34-36]. Stroke is associated with several pathophysiological changes, which leads to the expression of different blood-based biomarker patterns [37-49]. A biomarker is a small molecule that is usually a protein, which can be easily detected in biofluids (e.g., blood, plasma, saliva, and urine) and provide vital information on the condition of a specific organ, disease, or treatment [50]. An ideal biomarker is specific, sensitive, and selective. Stroke biomarkers are from different identified origins: glial cells, neuronal cells, heart muscle cells (cardiomyocytes), blood vessels cells (myocytes), general inflammatory cytokines, cytoskeleton proteins, hemostatic proteins, lipids, metabolic proteins, and others [51]. The biochemical pathways are different among different ischemic stroke mechanisms (e.g., atherosclerosis versus cardiac embolism) [27,52-56]. Over the past decades, the hypothesis that different blood biomarkers are associated with different ischemic stroke mechanisms is increasingly investigated [35,57-60]. This review presents the recent studies that investigated blood-based biomarker characteristics differentiation between ischemic stroke mechanisms. The different blood-based biomarkers that best indicate different ischemic stroke etiologies are specifically discussed (Table 1), as well as the different cut-off values that may be useful in specific etiology classifications for cardioembolic (Table 2) and atherosclerosis (Table 3) etiologies. The following biomarkers are discussed: b-type natriuretic peptide (BNP), d-dimer, c-reactive protein (CRP), tumor necrosis factor- $\alpha$ (TNF- $\alpha$ ), interleukin-6 (IL-6), interleukin-1 $\beta$ (IL-1 $\beta)$, neutrophil-lymphocyte ratio (NLR), total cholesterol, triglycerides, low-density lipoprotein (LDL), high-density lipoprotein (HDL) and apolipoprotein A. Lastly, the structure of a point-of-care biosensor device is presented, as a measuring tool for stroke biomarkers on-site. The information presented in this review will hopefully contribute to the major efforts that are being conducted to improve the care for stroke patients. 
Table 1. Blood-based biomarkers that best classify ischemic stroke etiologies, $\uparrow$ elevated vs. $\downarrow$ reduced.

\begin{tabular}{ccccc}
\hline Biomarker & Cardioembolic & Atherosclerosis & Lacunar & Ref. \\
\hline $\begin{array}{c}\text { B-Type Natriuretic Peptide } \\
\text { (BNP) }\end{array}$ & $\uparrow$ & $\downarrow$ & $\downarrow$ & [61-84] \\
\hline D-Dimer & $\uparrow$ & $\downarrow$ & $\downarrow$ & {$[72,80,85-98]$} \\
\hline C-Reactive Protein (CRP) & $\uparrow$ & $\uparrow$ & $\downarrow$ & [98-106] \\
\hline $\begin{array}{l}\text { Inflammatory Cytokines: } \\
\text { Tumor Necrosis Factor- } \alpha \\
\text { (TNF- } \alpha \text { ), Interleukin-6 (IL-6), } \\
\text { Interleukin-1 } \beta \text { (IL-1 } \beta \text { ) }\end{array}$ & $\uparrow$ & $\downarrow$ & $\downarrow$ & [89,107-109] \\
\hline $\begin{array}{c}\text { Neutrophil Lymphocyte } \\
\text { Ratio (NLR) }\end{array}$ & $\uparrow$ & $\uparrow$ & & \\
\hline $\begin{array}{c}\text { Common Lipid Panel: Total } \\
\text { Cholesterol, Triglycerides, } \\
\text { Low-Density Lipoprotein } \\
\text { (LDL), High-Density }\end{array}$ & & & & [110-116] \\
Lipoprotein (HDL) and & & & & \\
Apo-lipoprotein A & & & & \\
\hline
\end{tabular}

Table 2. Blood-based biomarkers that best indicate cardioembolic etiology.

\begin{tabular}{|c|c|c|}
\hline Biomarker & Finding & Study Ref. \\
\hline \multirow{5}{*}{$\begin{array}{l}\text { BNP (Cardiac } \\
\text { Biomarker) }\end{array}$} & $\begin{array}{c}\text { cardioembolic } \geq \\
\text { specificity }=80.5 \%)\end{array}$ & Shibazaki K. et al. 2009 [71] \\
\hline & $\begin{array}{c}\text { cardioembolic }=366.6 \mathrm{pg} / \mathrm{mL}, \text { vs. non-cardioembolic }=105.6 \mathrm{pg} / \mathrm{mL} \\
(p<0.01)\end{array}$ & Kawase S. et al. 2015 [63] \\
\hline & $\begin{aligned} \text { Cardioembolic } \geq & 66.5 \mathrm{pg} / \mathrm{mL} \text { (sensitivity }=76 \% \text { and a } \\
& \text { specificity }=87 \% \text { ) }\end{aligned}$ & Wu Z. et al. 2015 [65] \\
\hline & BNP predicted cardioembolic stroke (AUC ROC $=81 \%)$ & Nakamura M. et al. 2018 [79] \\
\hline & $\begin{array}{l}\text { BNP (sensitivity }=65 \%(95 \% \text { CI: } 63 \%-68 \%) \text { and specificity }=85 \% \\
(95 \% \text { CI: } 83 \%-87 \%) \text { ) and NT-proBNP (sensitivity }=55 \%(95 \% \text { CI: } \\
52 \%-59 \%) \text { and specificity }=93 \%(95 \% \text { CI: } 91 \%-94 \%))\end{array}$ & Bai J. et al. 2018 [77] \\
\hline \multirow{5}{*}{$\begin{array}{l}\text { D-Dimer } \\
\text { (Hemostatic } \\
\text { Biomarker) }\end{array}$} & D-dimer $\geq 300 \mathrm{ng} / \mathrm{mL}$ for distinguishing cardioembolic stroke & Takano K. et al. 1992 [94] \\
\hline & $\begin{array}{c}\text { D-dimer } \geq 2.00 \mathrm{mg} / \mathrm{mL} \text { for discriminating between the presence of a } \\
\text { cardioembolic source (specificity }=93 \% \text {, a sensitivity }=59 \% \text {, a } \\
\text { positive predictive value }=73 \% \text { and a negative predictive } \\
\text { value }=88 \% \text { ) }\end{array}$ & Ageno W. et al. 2002 [85] \\
\hline & D-dimer $\geq 1.6 \mathrm{mg} / \mathrm{L}$ may indicate cardioembolic stroke & Dougu N. et al. 2008 [86] \\
\hline & $\begin{array}{c}\text { D-dimer }=2.17 \mathrm{mg} / \mathrm{L}(\mathrm{IQR}, 1.24-3.48), \text { median levels were } \\
\text { significantly }(p=0.000) \text { higher in patients with cardioembolic stroke }\end{array}$ & Zi W.J. and J. Shuai 2014 [92] \\
\hline & $\begin{array}{c}\text { D-dimer } \geq 791.30 \mathrm{ng} / \mathrm{mL} \text { may indicate cardioembolic stroke } \\
\quad(\text { sensitivity }=58 \% \text { and a specificity }=78 \%)\end{array}$ & Liu L.-B. et al. 2015 [96] \\
\hline
\end{tabular}

CRP (Inflammatory Biomarker)

TNF- $\alpha$, IL-6 and IL1- $\beta$

(Inflammatory Cytokines)
CRP mean values were significantly higher in patients with cardioembolic stroke

Masotti L. et al. 2005 [99]

Cardioembolic patients showed significantly higher median plasma

levels of TNF- $\alpha$ (38.5 (22.2-46) pg/mL; $p<0.0001)$, IL-6 (11 (5.5-19)

Licata G. et al. 2009 [108]

Abbreviations: interquartile range (IQR); b-type natriuretic peptide (BNP); c-reactive protein (CRP); tumor necrosis factor- $\alpha$ (TNF- $\alpha)$, interleukin-6 (IL-6), interleukin-1 $\beta$ (IL-1 $\beta$ ). 
Table 3. Blood-based biomarkers that best indicate atherosclerosis etiology.

\begin{tabular}{|c|c|c|}
\hline Biomarker & Finding & Study Ref. \\
\hline \multirow{3}{*}{$\begin{array}{l}\text { CRP } \\
\text { (Inflammatory } \\
\text { Biomarker) }\end{array}$} & $\begin{array}{l}\text { Higher CRP levels were significantly found in patients with } \\
\text { atherosclerosis as compared to lacunar }\end{array}$ & $\begin{array}{l}\text { Suwanwela N.C. et al. } \\
\text { 2006'[100] }\end{array}$ \\
\hline & $\begin{array}{c}\text { In the acute phase the CRP levels were higher in cardioembolic than in } \\
\text { other etiologies (cardioembolic: } 7.07(2.39-17.8) \text {; atherosclerosis: } 4.66 \\
\text { (1.79-13.9); lacunar: } 3.08 \text { (1.52-5.79)). While, after } 3 \text { months, the CRP } \\
\text { levels were higher in atherosclerosis than in other etiologies } \\
\text { (cardioembolic: } 2.66 \text { (1.07-5.46); atherosclerosis: } 3.48 \text { (1.42-9.99); lacunar: } \\
2.65(1.26-4.82))\end{array}$ & $\begin{array}{l}\text { Ladenvall C. et al. } \\
\quad 2006[104]\end{array}$ \\
\hline & $\begin{array}{c}\text { The plasma levels of CRP were significantly }(p<0.05) \text { higher in } \\
\text { atherosclerosis etiology, with a cut off value of CRP } \geq 3.2 \text { demonstrating } \\
85.7 \% \text { classification sensitivity }\end{array}$ & Zeng L. et al. 2013 [105] \\
\hline \multirow{6}{*}{$\begin{array}{l}\text { NLR } \\
\text { (Inflammatory } \\
\text { Biomarker) }\end{array}$} & $\begin{array}{c}\text { Higher leukocyte counts in cardioembolic and atherosclerotic stroke } \\
\text { etiologies }\end{array}$ & $\begin{array}{l}\text { Elkind M.S. et al. } \\
\quad 2005 \text { [111] }\end{array}$ \\
\hline & $\begin{array}{l}\text { Both higher leukocyte and neutrophil counts were shown in great artery } \\
\text { atherosclerosis, while the counts were lower in the lacunar group }\end{array}$ & $\begin{array}{l}\text { Guven H. et al. } \\
2010[112]\end{array}$ \\
\hline & $\begin{array}{c}\text { NLR ratio level was significantly }(p<0.001) \text { higher in the great artery } \\
\text { atherosclerosis or atherothrombosis group }(6.67 \pm 3.74) \text { compared to the } \\
\text { other etiologies groups (cardioembolic: } 1.74 \pm 0.40 \text {; lacunar: } 3.75 \pm 1.74 ; \\
\text { unknown origin: } 3.00 \pm 1.49)\end{array}$ & $\begin{array}{l}\text { Gokhan S. et al. } \\
2013 \text { [110] }\end{array}$ \\
\hline & $\begin{array}{c}\text { NLR was significantly higher }(p=0.001) \text { in both the atherosclerotic }(6.5 \\
\text { (IQR 7.2)) and cardioembolic ( } 7.5 \text { (IQR 8.9)) stroke subgroups than the } \\
\text { lacunar infarct ( } 3.20 \text { (IQR 3.50)) subgroup }\end{array}$ & Tokgoz S. et al. 2013 [113] \\
\hline & $\begin{array}{l}\text { NLR level did not vary significantly among the stroke subtypes } \\
(p=0.070) \text {, while the neutrophil counts }\left(10^{3} / \mathrm{UL}\right) \text { were significantly } \\
(p=0.008) \text { different (large-artery disease }(5.3 \pm 1.5) \text {; cardioembolic } \\
(8.9 \pm 4.01) \text {; lacunar }(6.1 \pm 2.0) \text { and undetermined }(7.1 \pm 3.6))\end{array}$ & $\begin{array}{l}\text { Lök U. and U. Gülaçti } \\
\qquad 2016[115]\end{array}$ \\
\hline & $\begin{array}{l}\text { NLR levels in atherothrombotic and cardioembolic groups were } \\
3.26 \pm 2.35 \text { and } 4.46 \pm 5.6 \text {, respectively, and this was found to be } \\
\text { statistically significant }(p=0.03)\end{array}$ & $\begin{array}{l}\text { Domaç, F. et al. } \\
2019 \text { [114] }\end{array}$ \\
\hline \multirow{6}{*}{$\begin{array}{c}\text { Common } \\
\text { Lipid Panel: } \\
\text { Total } \\
\text { Cholesterol, } \\
\text { Triglycerides, } \\
\text { LDL, } \\
\text { and HDL }\end{array}$} & LDL-B is more prevalent in patients with atherosclerosis & Iskra T. et al. 2002 [117] \\
\hline & $\begin{array}{l}\text { Patients with atherosclerosis had significantly higher concentrations of } \\
\text { LDL than control }(p<0.05) \text {, higher concentrations of triglycerides, } \\
\text { and lower concentrations of HDL than patients with lacunar and control } \\
(p<0.05) \text {. LDL phenotype B was more frequent in patients with } \\
\text { atherosclerosis }(63.3 \%) \text { than in patients with lacunar }(39.0 \%) \text { or in control } \\
\qquad(16.7 \%)(p<0.05)\end{array}$ & $\begin{array}{l}\text { Slowik A. et al. } \\
2003[120]\end{array}$ \\
\hline & $\begin{array}{l}\text { The levels of total cholesterol were significantly higher in patients with } \\
\text { lacunar }(p=0.005) \text { and atherosclerosis }(p=0.018) \text { as compared to controls. } \\
\text { Patients with atherosclerosis etiology showed a significantly higher LDL } \\
\text { levels }(p<0.004) \text { and lower HDL levels }(p=0.001)\end{array}$ & Laloux P. et al. 2004 [119] \\
\hline & $\begin{array}{c}\text { HDL ratio was significantly higher in atherosclerosis vs. } \\
\text { non-atherosclerosis and non-lacunar patients. After adjustments, } \\
\text { significant ORs for atherosclerosis compared with all other ischemic } \\
\text { stroke subtypes were triglycerides (OR 2.69, 95\% CI 1.44 to 5.02) and } \\
\text { non-HDL (OR 2.39, 95\% CI } 1.40 \text { to } 4.11 \text { ) }\end{array}$ & $\begin{array}{l}\text { Bang O.Y. et al. } \\
2008 \text { [118] }\end{array}$ \\
\hline & $\begin{array}{c}\text { Hazard ratios of ischemic stroke with serum total cholesterol levels } \\
\text { among large-artery patients for men }(2.86(1.31-6.27)) \text { and women }(0.75 \\
(0.28-2.01)) \text {, while they were not associated with risk of lacunar or } \\
\text { embolic infarction }\end{array}$ & Cui R. et al. 2012 [122] \\
\hline & $\begin{array}{l}\text { The levels of total cholesterol, triglycerides, LDL, apolipoprotein A, } \\
\text { apolipoprotein B, apolipoprotein E, and lipoprotein A were higher and } \\
\text { HDL was lower in stroke patients with atherosclerosis etiology as } \\
\text { compared to the cardioembolic etiology. The levels of lipoprotein A, total } \\
\text { cholesterol, and total cholesterol/HDL were higher in patients with } \\
\text { cardioembolic etiology as compared to the lacunar etiology. The levels of } \\
\text { total cholesterol, triglycerides, LDL, apolipoprotein A, apolipoprotein B, } \\
\text { apolipoprotein E, lipoprotein A, total cholesterol/HDL, and LDL/HDL } \\
\text { were all significantly different between patients with atherosclerosis } \\
\text { etiology as compared to that with lacunar etiology }\end{array}$ & $\begin{array}{l}\text { Yuan B.-B. et al. } \\
2015 \text { [121] }\end{array}$ \\
\hline
\end{tabular}


Table 3. Cont.

\begin{tabular}{cccc}
\hline Biomarker & Finding & Study Ref. \\
\hline & The percentage of subjects with increased lipoprotein A concentrations & \\
& $($ i.e., $>30 \mathrm{mg} / \mathrm{dL})$ was greater in large vessel disease $(36.7 \%)$ than in small & Iskra T. et al. 2002 [117] \\
& vessel disease $(12.2 \% ; p<0.05)$ and in controls $(10 \% ; p<0.05)$ & \\
\cline { 2 - 4 } Apo- & Subjects carrying at least one small Apo-lipoprotein A isoform were at & Zambrelli E. et al. \\
increased risk of atherothrombotic stroke (OR 7.1, 95\% CI 2.8 to 17.5, & 2005 [123] \\
& $p=0.00001)$ but not of lacunar infarction (OR 1.1, 95\% CI 0.5 to 2.7, & $p=0.78)$ &
\end{tabular}

Lipoprotein A levels of atherosclerosis stroke $(n=281,34.6 \mathrm{mg} / \mathrm{dL})$ were significantly $(p<0.001)$ higher as compared to other stroke mechanisms (cardioembolic: $n=204,29.2 \mathrm{mg} / \mathrm{dL}$, lacunar: $n=261,24.2 \mathrm{mg} / \mathrm{dL}$, other determined: $n=74,24.1 \mathrm{mg} / \mathrm{dL}$, undetermined: $n=192,27 \mathrm{mg} / \mathrm{dL})$

Abbreviations: c-reactive protein (CRP); neutrophil-lymphocyte ratio (NLR); low-density lipoprotein (LDL); high-density lipoprotein (HDL).

\section{Biomarkers that Best Indicate Cardioembolic Etiology}

\subsection{B-Type Natriuretic Peptide (BNP)}

Over the past decades, b-type natriuretic peptide (BNP) and its derivative N-terminal fragment (NT-proBNP) have been reported as cardiovascular biomarkers, mainly for heart failure (HF) diagnosis as well as for stroke monitoring [125,126]. BNP (32 aa) is secreted by heart ventricles after excessive stretching of cardiomyocytes (heart muscle cells) [127]. NT-proBNP (76 aa) is secreted along with BNP and is biologically inactive [128]. BNP reflects on the ventricular condition with a half-life of $20 \mathrm{~min}$, while NT-proBNP showed a half-life of 1-2 h [129]. Multiple studies reported that both BNP and NT-proBNP elevated serum levels are associated with cardioembolic stroke [61-84]. Additionally, they were found to be associated with atrial fibrillation (AF) condition, an abnormal heart rhythm (arrhythmia), that increases the risk of ischemic stroke and was also found to be associated with cardioembolic stroke [130]. Shibazaki K. et al. [71] reported that a BNP plasma level higher than $140 \mathrm{pg} / \mathrm{mL}$ is associated with patients with cardioembolic stroke, with a sensitivity $=80.5 \%$ and a specificity $=80.5 \%$. Moreover, Kawase S. et al. [63] reported that the plasma level of BNP was higher in the case of cardioembolic stroke $(366.6 \mathrm{pg} / \mathrm{mL})$ compared to non-cardioembolic stroke $(105.6 \mathrm{pg} / \mathrm{mL}$; $p<0.01)$. Llombart V. et al. [64] reported that higher levels of BNP and NT-proBNP in the blood were significantly associated with cardioembolic stroke up to $72 \mathrm{~h}$ after stroke symptoms onset. Moreover, Chaudhuri J. R. et al. [61] reported that higher BNP levels were observed in $75 \%$ of cardioembolic stroke patients, while in the rest of the stroke etiologies: in $45.8 \%$ of lacunar patients, in $43.1 \%$ of atherosclerosis patients, and 34.5\% of undetermined etiology. Moreover, Bai J. et al. [77] reported that both BNP (sensitivity $=65 \%(95 \%$ CI: $63 \%-68 \%)$ and specificity $=85 \%(95 \%$ CI: $83 \%-87 \%)$ ) and NT-proBNP (sensitivity $=55 \%$ (95\% CI: 52\%-59\%) and specificity $=93 \%(95 \%$ CI: $91 \%-94 \%)$ ) were associated with cardioembolic stroke. Additionally, Nakamura M. et al. [79] reported that BNP predicted cardioembolic stroke (area under the receiver operating characteristic (AUC ROC) $=81 \%)$ ). In addition to these findings, Wu Z. et al. [65] examined a point-of-care (POC) test for plasma BNP detection in the emergency department (ED), to promote initial recognition of cardioembolic stroke patients. BNP concentration was higher in the cardioembolic group $(p<0.01)$, a plasma BNP level higher than $66.5 \mathrm{pg} / \mathrm{mL}$ was associated with cardioembolic stroke (sensitivity $=76 \%$ and a specificity $=87 \%$ ). In another study by Wu Z. et al. [74], the plasma BNP level was also measured at bedside. To conclude, BNP detection at bedside on admission can be added into stroke management as a strategy to improve the classification of stroke etiology.

\subsection{D-Dimer}

D-dimer is a by-product of fibrin degradation by plasmin and is a well-known hemostatic biomarker for blood coagulation activation and thrombosis, the formation of blood clot [131]. It was found useful for the diagnosis of venous thromboembolism and disseminated intravascular coagulation [132]. Multiple 
studies reported that elevated levels of D-dimer are associated with cardioembolic stroke [72,80,85-98]. Takano K. et al. [94] reported a D-dimer cut-off point of $300 \mathrm{ng} / \mathrm{mL}$ for distinguishing cardioembolic stroke from atherothrombotic infarction and lacunar infarction, with a sensitivity $=80 \%$ and a specificity $=77 \%$. Additionally, Ageno W. et al. [85] reported that the optimal D-dimer cut-off point for discriminating between the presence and absence of a cardioembolic source is $2.00 \mathrm{mg} / \mathrm{mL}$, with a specificity $=93 \%$, a sensitivity $=59 \%$, a positive predictive value $=73 \%$, and a negative predictive value $=88 \%$. Additionally, Dougu N. et al. [86] reported that D-dimer level higher than $1.6 \mathrm{mg} / \mathrm{L}$ $(=1600 \mathrm{ng} / \mathrm{mL})$ may indicate a high possibility of cardioembolic stroke. Moreover, Zi W. J. and J. Shuai [92] examined d-dimer levels measured upon admission (0-48 h from stroke symptom onset) and reported that median D-dimer levels were significantly $(p=0.000)$ higher in patients with cardioembolic stroke (2.17 mg/L (interquartile range (IQR), 1.24-3.48)), as compared with small-vessel occlusive stroke (0.59 mg/L (IQR, 0.25-0.96)), large-vessel occlusive stroke (0.56 mg/L (IQR, 0.22-0.95)), other stroke $(0.25 \mathrm{mg} / \mathrm{L}(\mathrm{IQR}, 0.14-0.41))$ and unknown stroke $(0.29 \mathrm{mg} / \mathrm{L}(\mathrm{IQR}, 0.18-0.68))$. D-dimer median level was higher in patients with cardioembolic strokes than in those with other etiologies (2.17 vs. $0.47 \mathrm{mg} / \mathrm{L}, p=0.000$ ). The receiver operating characteristic (ROC) analysis revealed the optimal cut-off value of plasma D-dimer levels as an indicator for diagnosis of cardioembolic strokes to be $0.91 \mathrm{mg} / \mathrm{L}(=910 \mathrm{ng} / \mathrm{mL})$, with a sensitivity $=83.7 \%$ and a specificity $=81.5 \%$, the area under the curve $(\mathrm{AUC})=86.2 \%(95 \%$ confidence interval (CI), 81.1\%-91.2\%). Additional studies reported different cut-off values of d-dimer level as an indication of cardioembolic stroke. Additionally, Liu L.-B. et al., [96] reported that D-dimer level higher than $791.30 \mathrm{ng} / \mathrm{mL}$ may indicate cardioembolic stroke, with a sensitivity $=58 \%$ and a specificity $=78 \%$. Hirano K. et al. [93] reported that additional fibrin degradation products may also be associated with cardioembolic stroke. The levels of fibrin monomer complex (FMC), soluble fibrin (SF) and fibrin/fibrinogen degradation products (FDPs) were significantly higher in the cardioembolic group. The findings reported in these studies suggest that D-dimer levels in the acute stage of ischemic stroke might be useful in distinguishing cardioembolic stroke. Furthermore, the level of D-dimer is very rarely elevated in healthy individuals; however, it may increase in several illnesses and physiological conditions associated with thrombosis and thrombolysis [91].

\subsection{Inflammatory Biomarkers: C-Reactive Protein (CRP), Tumor Necrosis Factor- $\alpha$ (TNF- $\alpha$ ), Interleukin-6 (IL-6), Interleukin-1 $\beta(I L-1 \beta)$}

Over the past years, evidence was found for the value of inflammatory biomarkers in cerebral cardioembolism, after inflammation was reported to be involved in atrial fibrillation [133] and thromboembolic events [134]. Several studies reported that elevated levels of the inflammatory biomarkers, c-reactive protein (CRP), tumor necrosis factor- $\alpha$ (TNF- $\alpha)$, interleukin-6 (IL-6), interleukin-1 $\beta$ (IL-1 $\beta$ ), are associated with cardioembolic stroke [89,98-103,107-109]. Masotti L. et al. [99] examined CRP levels within $12 \mathrm{~h}$ from hospital admission among all ischemic stroke etiologies. The mean values of CRP were significantly higher in patients with cardioembolic stroke compared with an atherothrombotic large vessel and lacunar stroke. It was also previously reported that D-dimer itself stimulates monocyte synthesis and release of pro-inflammatory cytokines such as IL-6 [89]. Furthermore, Licata G. et al. [108] evaluated the plasma levels of immuno-inflammatory biomarkers in patients with cardioembolic ischemic stroke. Cardioembolic patients showed significantly higher median plasma levels of TNF- $\alpha$ (38.5 (22.2-46) pg/mL; $p<0.0001)$, IL-6 (11 (5.5-19) pg/mL; $p=0.0029)$ and IL1- $\beta(11.5(8-13) \mathrm{pg} / \mathrm{mL} ; p<0.0001)$.

\section{Biomarkers that Best Indicate Atherosclerosis Etiology}

\subsection{Inflammatory Biomarkers: C-Reactive Protein (CRP) and Neutrophil-Lymphocyte Ratio (NLR)}

Inflammatory biomarkers were previously found to be generally associated with atherosclerosis [135]. Higher CRP levels were found to be associated with atherosclerosis stroke [98,100,104-106]. Suwanwela N. C. et al. [100] examined the levels of inflammatory markers 
among patients with large vessel atherosclerosis (LAAS) and small vessel disease (lacunar stroke) and reported that higher CRP levels were significantly found in patients with large vessel disease. Additionally, Ladenvall C. et al. [104] reported that in the acute phase the CRP levels were higher in cardioembolic than in other etiologies (cardioembolic: 7.07 (2.39-17.8); atherosclerosis: 4.66 (1.79-13.9); lacunar: 3.08 (1.52-5.79)). While, after three months, the CRP levels were higher in atherosclerosis than in other etiologies (cardioembolic: 2.66 (1.07-5.46); atherosclerosis: 3.48 (1.42-9.99); lacunar: 2.65 (1.26-4.82)). Moreover, Zeng L. et al. [105] reported that the plasma levels of CRP were significantly $(p<0.05)$ higher in atherosclerosis etiology, with a cut off value of CRP $\geq 3.2$ demonstrating $85.7 \%$ classification sensitivity. Moreover, neutrophil-lymphocyte ratio (NLR), which is calculated by dividing the concentration of neutrophils by the concentration of lymphocytes, was reported to indicate ischemic stroke from atherosclerosis etiology, as well as in cardioembolic etiology [110-116]. NLR is an inflammatory marker that has been recently introduced and examined in several coronary artery disease studies [136-140]. Elkind M. S. et al. [111] reported higher leukocyte counts in cardioembolic and atherosclerotic stroke etiologies. Moreover, Guven H. et al. [112] reported both higher leukocyte and neutrophil counts in great artery atherosclerosis, while the counts were lower in the lacunar group. Additionally, Gokhan S. et al. [110] reported that the NLR ratio level was significantly $(p<0.001)$ higher in the great artery atherosclerosis or atherothrombosis group $(6.67 \pm 3.74)$ compared to the other etiologies groups (cardioembolic: $1.74 \pm 0.40$; lacunar: $3.75 \pm 1.74$; unknown origin: $3.00 \pm 1.49$ ). Tokgoz S. et al. [113] also reported that the NLR was significantly higher $(p=0.001)$ in both the atherosclerotic (6.5 (IQR 7.2)) and cardioembolic (7.5 (IQR 8.9)) stroke subgroups than the lacunar infarct (3.20 (IQR 3.50)) subgroup. Lök U. and U. Gülaçti [115] reported that the NLR level did not vary significantly among the stroke subtypes $(p=0.070)$, while the neutrophil counts $\left(10^{3} / \mu \mathrm{L}\right)$ were significantly $(p=0.008)$ different (large-artery disease $(5.3 \pm 1.5)$; cardioembolic $(8.9 \pm 4.01)$; lacunar $(6.1 \pm 2.0)$ and undetermined $(7.1 \pm 3.6))$. Domaç, F. et al. [114] reported that the NLR levels in atherothrombotic and cardioembolic groups were $3.26 \pm 2.35$ and $4.46 \pm 5.6$, respectively, and this was found to be statistically significant $(p=0.03)$.

\subsection{Common Lipid Panel: Total Cholesterol, Triglycerides, Low-Density Lipoprotein (LDL), and High-Density Lipoprotein (HDL)}

Serum lipids have been investigated for their association with different ischemic stroke mechanisms [117-122]. Iskra T. et al. [117] reported that LDL-B is also more prevalent in patients with atherosclerosis. Moreover, Slowik A. et al. [120] reported that patients with atherosclerosis had significantly higher concentrations of LDL than control $(p<0.05)$, and had higher concentrations of triglycerides and lower concentrations of HDL than patients with lacunar and control $(p<0.05)$. LDL phenotype B was more frequent in patients with atherosclerosis $(63.3 \%)$ than in patients with lacunar $(39.0 \%)$ or in control $(16.7 \%)(p<0.05)$. Additionally, Laloux P. et al. [119] investigated whether the lipid profile (total cholesterol, LDL, HDL, and triglycerides) of patients with atherosclerosis etiology is different than that of patients with lacunar etiology, which are both responsible for atherothrombotic cerebral ischemia. The study cohort $(n=485)$ was further selected into 240 patients with ischemic stroke $(n=182)$ or transient ischemic attack $(n=58)$ with a single classified etiology (61 patients with atherosclerosis, 65 with lacunar and 114 with cardioembolic). The levels of total cholesterol were significantly higher in patients with lacunar $(p=0.005)$ and atherosclerosis $(p=0.018)$ as compared to controls. The levels of triglycerides were significantly higher among all stroke etiologies as compared to controls (cardioembolic, $p=0.037$; lacunar, $p<0.001$; atherosclerosis, $p=0.014$ ). Patients with atherosclerosis etiology showed a significantly higher LDL levels $(p<0.004)$ and lower HDL levels $(p=0.001)$. Only HDL levels were significantly $(p=0.047)$ different between patients with atherosclerosis etiology and with lacunar etiology, also in adjusted logistic regression analysis. Additionally, Bang O. Y. et al. [118] investigated the association of large artery atherosclerotic stroke with common serum lipid panel, including total cholesterol, triglycerides, low-density lipoprotein (LDL), high-density lipoprotein (HDL), and triglyceride. The study cohort included a large stroke 
patient number $(n=1049)$, classified to the following etiologies: $247(23.5 \%)$ atherosclerosis, $224(21.4 \%)$ lacunar, and 578 (55\%) were non-atherosclerosis and non-lacunar group. The levels of total cholesterol, triglycerides, LDL, non-high-density lipoprotein cholesterol (HDL), and triglyceride:HDL ratio was significantly higher in atherosclerosis vs. non-atherosclerosis and non-lacunar patients, while the lipids levels were similar between atherosclerosis and lacunar patients. After adjustments, significant odds ratios (ORs) for atherosclerosis compared with all other ischemic stroke subtypes were triglycerides (OR 2.69, 95\% CI 1.44 to 5.02) and non-HDL (OR 2.39, 95\% CI 1.40 to 4.11). LDL was not found to be associated with atherosclerosis etiology. Moreover, Cui R. et al., [122] reported the hazard ratios of ischemic stroke with serum total cholesterol levels among large-artery patients for men (2.86 (1.31-6.27)) and women $(0.75(0.28-2.01))$, while they were not associated with risk of lacunar or embolic infarction. Additionally, Yuan B.-B. et al. [121] reported that the levels of total cholesterol, triglycerides, LDL, apolipoprotein A, apolipoprotein B, apolipoprotein E, and lipoprotein A were higher and HDL was lower in stroke patients with atherosclerosis etiology as compared to the cardioembolic etiology. The levels of lipoprotein A, total cholesterol, and total cholesterol/HDL were higher in patients with cardioembolic etiology as compared to the lacunar etiology. The levels of total cholesterol, triglycerides, LDL, apolipoprotein A, apolipoprotein B, apolipoprotein E, lipoprotein A, total cholesterol/HDL, and LDL/HDL were all significantly different between patients with atherosclerosis etiology as compared to that with lacunar etiology. The levels of total cholesterol/HDL were different among all stroke etiologies, and the patients with atherosclerosis etiology showed the highest level.

\subsection{Apolipoprotein A}

Apolipoprotein A belongs to the group of low-density lipoprotein (LDL), and it is associated with ischemic stroke from atherosclerosis etiology [117,123,124]. Iskra T. et al. [117] investigated the levels of lipoprotein A in ischemic stroke patients. Serum lipoprotein A is a lipoprotein consisting of apolipoprotein A and apolipoprotein B-100. It was found that median concentrations of lipoprotein A were similar in all studied groups $(8.4 \mathrm{mg} / \mathrm{dL}$ in all stroke patients; $10.85 \mathrm{mg} / \mathrm{dL}$ in large vessel disease; $7.7 \mathrm{mg} / \mathrm{dL}$ in small vessel disease and $6.3 \mathrm{mg} / \mathrm{dL}$ in controls; $p=$ non-significant). The percentage of subjects with increased lipoprotein A concentrations (i.e., $>30 \mathrm{mg} / \mathrm{dL}$ ) was greater in large vessel disease $(36.7 \%)$ than in small vessel disease $(12.2 \% ; p<0.05)$ and in controls $(10 \% ; p<0.05)$. Additionally, Zambrelli E. et al. [123] investigated the levels of apolipoprotein A in ischemic stroke patients $(n=94)$, as well as its association with different etiologies and stroke severity, as compared to healthy control (188). It was found that subjects carrying at least one small apolipoprotein A isoform were at increased risk of atherothrombotic stroke (OR 7.1, 95\% CI 2.8 to 17.5, $p=0.00001$ ) but not of lacunar infarction (OR 1.1, 95\% CI 0.5 to 2.7, $p=0.78$ ). Multivariate logistic regression analysis revealed that in the atherothrombotic stroke group, the presence of at least one small-sized apolipoprotein A phenotype was associated with a National Institutes of Health Stroke Scale (NIHSS) score $>$ or $=6$ (OR 13.6, $95 \%$ CI 1.6 to $111.9, p=0.015)$. They concluded that small apolipoprotein A isoforms distinguish atherothrombotic stroke from lacunar infarction and are associated with the severity of atherothrombotic stroke. Furthermore, Kim B. S. et al. [124] reported that lipoprotein A levels of atherosclerosis stroke ( $n=281,34.6 \mathrm{mg} / \mathrm{dL})$ were significantly $(p<0.001)$ higher as compared to other stroke mechanisms (cardioembolic: $n=204,29.2 \mathrm{mg} / \mathrm{dL}$, lacunar: $n=261,24.2 \mathrm{mg} / \mathrm{dL}$, other determined: $n=74,24.1 \mathrm{mg} / \mathrm{dL}$, undetermined: $n=192,27 \mathrm{mg} / \mathrm{dL})$.

\section{Point-of-Care Biosensor as On-Site Test for Blood-Based Biomarker Detection}

A point-of-care (POC) biosensor is a rapid on-site test that provides results within minutes. It is usually easy to operate, has a robust setup, and requires a small sample volume without any pretreatment [141,142]. Two famous examples of successful POC biosensors are the lateral-flow pregnancy test and the glucometer [143]. Routinely, biomarkers are usually detected by an enzyme-linked immunosorbent assay (ELISA), which is the most common immunoassay methodology [144]. It obtains highly sensitivity results; however, it is complicated, time-consuming, 
and consists of multiple steps. A POC biosensor may provide a more practical solution while still obtaining sufficient sensitivity $[145,146]$. A biosensor consists of a biorecognition entity (e.g., antibodies, antigens, DNA/RNA, whole cells, enzymes, or biomimetic molecules), which enables the detection of the target biological molecule. The interface is the main structure of the biosensor that allows its function, and it is usually based on adsorption, cross-linking, covalent binding, entrapment, self-assembled monolayers, and bulk modifications. Lastly, the transducer allows the signal measurement that is from optical, electrochemical, or acoustic origin $[147,148]$. There are different POC biosensor analytical formats such as paper-based [149-151], optical [152,153], electrochemical [154] and microfluidics [155]. Most of the POC biosensor platforms allow the detection of a single chosen biomarker. The development of a multi-biomarker detection device is still mostly research-based. Additionally, a quantitative biomarker detection is needed that allows the identification of a specific cut-off value relevant in the clinical setting, which will enable an improved decision-making process. To develop multiplex and quantitative POC biosensors for stroke biomarker measurement, there is a need to engineer novel platforms. Various POC biosensors have been clinically tested for their usefulness in stroke care [156]. These POC biosensors include different well-known biomarker detection: coagulation profile (international normalized ratio (INR), activated partial thromboplastin time (APTT)), blood-count (platelet, leukocyte, and erythrocyte count), and blood-chemistry (hemoglobin, glucose, c-glutamyltransferase, and p-amylase test) [15,157-160]. Unfortunately, these valuable tools are still not fully incorporated into the current clinical practice due to the time-consuming diagnostic procedures. For example, most of the guidelines for the management of stroke patients indicate that thrombolytic therapy should not be delayed on the account of these mentioned test results, with the only exceptions being bleeding abnormality, thrombocytopenia, and admission of anticoagulants [161]. Currently, half of stroke patients are misdiagnosed in the ED [162], while the clinical management scheme is still solely based on the assessment of symptoms and stroke scale tools [163]. There is a need for immediate and unbiased tools for the monitoring of stroke patients.

\section{Conclusions}

This review presents the recent studies that investigated blood-based biomarker characteristics differentiation between ischemic stroke mechanisms. Different blood-based biomarkers are specifically discussed, as well as the different cut-off values that may be useful in specific etiology classifications for cardioembolic and atherosclerosis etiologies. Various blood-based biomarkers were found to be significantly associated with ischemic stroke from cardioembolic etiology including BNP/NT-proBNP, d-dimer, CRP, TNF- $\alpha$, IL-6, and IL-1 $\beta$. Furthermore, various blood-based biomarkers were found to be significantly associated with ischemic stroke from atherosclerosis etiology including CRP, NLR, total cholesterol, triglycerides, LDL, HDL, and apolipoprotein A. Increased research efforts are still needed to identify useful biomarkers to differentiate ischemic stroke from lacunar etiology $[164,165]$. Lastly, the structure of a POC biosensor device is presented, as a measuring tool for stroke biomarkers on-site. A POC biosensor is a rapid on-site test that provides results within minutes. It is usually easy to operate, has a robust setup, and requires a small sample volume without any pretreatment. To develop multiplex and quantitative POC biosensors for stroke biomarker measurement there is a need to engineer novel platforms. The information presented in this review will hopefully contribute to the major efforts that are conducted to improve the care for stroke patients.

Author Contributions: Conceptualization, D.H., R.C.S.S., R.S.M., A.I.Y.T.; writing—original draft preparation, D.H.; review and editing, R.C.S.S., R.S.M, A.I.Y.T.; visualization, D.H.; supervision, R.S.M, A.I.Y.T.; project administration, R.S.M, A.I.Y.T. All authors have read and agreed to the published version of the manuscript.

Funding: This research was funded by the National Research Foundation (NRF) of Singapore under the Campus for Research Excellence and Technological Enterprise (CREATE) and the Singapore International Graduate Award (SINGA) for supporting D.H.

Conflicts of Interest: The authors declare no potential conflicts of interest concerning the research, authorship, and/or publication of this article. 


\section{References}

1. Hawkes, M.A.; Rabinstein, A.A. Acute Ischemic Stroke. In Neurological Emergencies: A Practical Approach; Rabinstein, A.A., Ed.; Springer International Publishing: Cham, Switzerland, 2020; pp. 171-188.

2. American Heart \& Stroke Association. Types of Stroke. Available online: https://www.stroke.org/en/aboutstroke/types-of-stroke (accessed on 1 August 2020).

3. Mehndiratta, P.; Smith, S.C.; Worrall, B.B. Etiologic stroke subtypes: Updated definition and efficient workup strategies. Curr. Treat. Options Cardiovasc. Med. 2015, 17, 357. [CrossRef] [PubMed]

4. Amarenco, P.; Bogousslavsky, J.; Caplan, L.R.; Donnan, G.A.; Hennerici, M.G. Classification of stroke subtypes. Cerebrovasc. Dis. 2009, 27, 493-501. [CrossRef] [PubMed]

5. Mac Grory, B.; Flood, S.P.; Apostolidou, E.; Yaghi, S. Cryptogenic Stroke: Diagnostic Workup and Management. Curr. Treat. Options Cardiovasc. Med. 2019, 21, 77. [CrossRef] [PubMed]

6. Yaghi, S.; Bernstein, R.A.; Passman, R.; Okin, P.M.; Furie, K.L. Cryptogenic stroke: Research and practice. Circ. Res. 2017, 120, 527-540. [CrossRef]

7. Hacke, W.; Kaste, M.; Bluhmki, E.; Brozman, M.; Davalos, A.; Guidetti, D.; Larrue, V.; Lees, K.R.; Medeghri, Z.; Machnig, T.; et al. Thrombolysis with alteplase 3 to 4.5 hours after acute ischemic stroke. N. Engl. J. Med. 2008, 359, 1317-1329. [CrossRef]

8. Sandercock, P.; Wardlaw, J.M.; Lindley, R.I.; Dennis, M.; Cohen, G.; Murray, G.; Innes, K.; Venables, G.; Czlonkowska, A.; Kobayashi, A.; et al. The benefits and harms of intravenous thrombolysis with recombinant tissue plasminogen activator within $6 \mathrm{~h}$ of acute ischaemic stroke (the third international stroke trial [IST-3]): A randomised controlled trial. Lancet 2012, 379, 2352-2363.

9. Kernan, W.N.; Ovbiagele, B.; Black, H.R.; Bravata, D.M.; Chimowitz, M.I.; Ezekowitz, M.D.; Fang, M.C.; Fisher, M.; Furie, K.L.; Heck, D.V. Guidelines for the prevention of stroke in patients with stroke and transient ischemic attack: A guideline for healthcare professionals from the American Heart Association/American Stroke Association. Stroke J. Cereb. Circ. 2014, 45, 2160-2236. [CrossRef]

10. García-Berrocoso, T.; Palà, E.; Consegal, M.; Piccardi, B.; Negro, A.; Gill, N.; Penalba, A.; Encabo, H.H.; Fernández-Cadenas, I.; Meisel, A. Cardioembolic ischemic stroke gene expression fingerprint in blood: A systematic review and verification analysis. Transl. Stroke Res. 2020, 11, 326-336. [CrossRef]

11. Audebert, H.J.; Saver, J.L.; Starkman, S.; Lees, K.R.; Endres, M. Prehospital stroke care: New prospects for treatment and clinical research. Neurology 2013, 81, 501-508. [CrossRef]

12. Leys, D.; Ringelstein, E.B.; Kaste, M.; Hacke, W. Facilities available in European hospitals treating stroke patients. Stroke J. Cereb. Circ. 2007, 38, 2985-2991. [CrossRef]

13. Fladt, J.; Meier, N.; Thilemann, S.; Polymeris, A.; Traenka, C.; Seiffge, D.J.; Sutter, R.; Peters, N.; Gensicke, H.; Flückiger, B. Reasons for Prehospital Delay in Acute Ischemic Stroke. J. Am. Heart Assoc. 2019, 8, e013101. [CrossRef] [PubMed]

14. Sharobeam, A.; Jones, B.; Walton-Sonda, D.; Lueck, C.J. Factors delaying intravenous thrombolytic therapy in acute ischaemic stroke: A systematic review of the literature. J. Neurol. 2020, 1-12. [CrossRef] [PubMed]

15. Tai, Y.J.; Yan, B. Minimising time to treatment: Targeted strategies to minimise time to thrombolysis for acute ischaemic stroke. Intern. Med. J. 2013, 43, 1176-1182. [CrossRef]

16. Evenson, K.R.; Rosamond, W.D.; Morris, D.L. Prehospital and in-hospital delays in acute stroke care. Neuroepidemiology 2001, 20, 65-76. [CrossRef] [PubMed]

17. Campbell, B.C.; De Silva, D.A.; Macleod, M.R.; Coutts, S.B.; Schwamm, L.H.; Davis, S.M.; Donnan, G.A. Ischaemic stroke. Nat. Rev. Dis. Primers 2019, 5, 1-22. [CrossRef]

18. Joshi, B. Stroke Diagnostics and Therapeutics: Global Markets; HLC180A; BCC Research: Wellesley, MA, USA, 2015.

19. Goldstein, L.B.; Adams, R.; Alberts, M.J.; Appel, L.J.; Brass, L.M.; Bushnell, C.D.; Culebras, A.; Degraba, T.J.; Gorelick, P.B.; Guyton, J.R.; et al. Primary prevention of ischemic stroke: A guideline from the American Heart Association/American Stroke Association Stroke Council: Cosponsored by the Atherosclerotic Peripheral Vascular Disease Interdisciplinary Working Group; Cardiovascular Nursing Council; Clinical Cardiology Council; Nutrition, Physical Activity, and Metabolism Council; and the Quality of Care and Outcomes Research Interdisciplinary Working Group: The American Academy of Neurology affirms the value of this guideline. Stroke 2006, 37, 1583-1633. 
20. Rothwell, P.M.; Coull, A.J.; Silver, L.E.; Fairhead, J.F.; Giles, M.F.; Lovelock, C.E.; Redgrave, J.N.; Bull, L.M.; Welch, S.J.; Cuthbertson, F.C.; et al. Population-based study of event-rate, incidence, case fatality, and mortality for all acute vascular events in all arterial territories (Oxford Vascular Study). Lancet 2005, 366, 1773-1783. [CrossRef]

21. Chen, R.L.; Balami, J.S.; Esiri, M.M.; Chen, L.K.; Buchan, A.M. Ischemic stroke in the elderly: An overview of evidence. Nat. Rev. Neurol. 2010, 6, 256-265. [CrossRef]

22. MacKay-Lyons, M.; Gubitz, G.; Giacomantonio, N.; Wightman, H.; Marsters, D.; Thompson, K.; Blanchard, C.; Eskes, G.; Thornton, M. Program of rehabilitative exercise and education to avert vascular events after non-disabling stroke or transient ischemic attack (PREVENT Trial): A multi-centred, randomised controlled trial. BMC Neurol. 2010, 10, 122. [CrossRef]

23. Huang, Z.-X.; Lin, X.-L.; Lu, H.-K.; Liang, X.-Y.; Fan, L.-J.; Liu, X.-T. Lifestyles correlate with stroke recurrence in Chinese inpatients with first-ever acute ischemic stroke. J. Neurol. 2019, 266, 1194-1202. [CrossRef]

24. Petty, G.W.; Brown, R.D., Jr.; Whisnant, J.P.; Sicks, J.R.D.; O’Fallon, W.M.; Wiebers, D.O. Ischemic stroke subtypes: A population-based study of incidence and risk factors. Stroke J. Cereb. Circ. 1999, 30, 2513-2516. [CrossRef] [PubMed]

25. Lodder, J.; Bamford, J.M.; Sandercock, P.A.G.; Jones, L.N.; Warlow, C.P. Are hypertension or cardiac embolism likely causes of lacunar infarction? Stroke J. Cereb. Circ. 1990, 21, 375-381. [CrossRef] [PubMed]

26. Grau, A.J.; Weimar, C.; Buggle, F.; Heinrich, A.; Goertler, M.; Neumaier, S.; Glahn, J.; Brandt, T.; Hacke, W.; Diener, H.-C. Risk Factors, Outcome, and Treatment in Subtypes of Ischemic Stroke. Ger. Stroke Data Bank 2001, 32, 2559-2566.

27. Lee, L.J.; Kidwell, C.S.; Alger, J.; Starkman, S.; Saver, J.L. Impact on stroke subtype diagnosis of early diffusion-weighted magnetic resonance imaging and magnetic resonance angiography. Stroke J. Cereb. Circ. 2000, 31, 1081-1089. [CrossRef]

28. Adams, H.P., Jr.; Bendixen, B.H.; Kappelle, L.J.; Biller, J.; Love, B.B.; Gordon, D.L.; Marsh, E.E., 3rd. Classification of subtype of acute ischemic stroke. Definitions for use in a multicenter clinical trial. TOAST. Trial of Org 10172 in Acute Stroke Treatment. Stroke J. Cereb. Circ. 1993, 24, 35-41. [CrossRef] [PubMed]

29. Landau, W.M.; Nassief, A. Editorial comment-Time to burn the TOAST. Stroke J. Cereb. Circ. 2005, 36, 902-904. [CrossRef]

30. Amarenco, P. Patent foramen ovale and the risk of stroke: Smoking gun guilty by association? Heart (British Cardiac Society) 2005, 91, 441-443. [CrossRef]

31. Sacco, R.L.; Ellenberg, J.H.; Mohr, J.P.; Tatemichi, T.K.; Hier, D.B.; Price, T.R.; Wolf, P.A. Infarcts of undetermined cause: The NINCDS Stroke Data Bank. Ann. Neurol. 1989, 25, 382-390. [CrossRef] [PubMed]

32. Bamford, J.; Sandercock, P.; Dennis, M.; Burn, J.; Warlow, C. Classification and natural history of clinically identifiable subtypes of cerebral infarction. Lancet 1991, 337, 1521-1526. [CrossRef]

33. Lindley, R.I.; Warlow, C.P.; Wardlaw, J.M.; Dennis, M.S.; Slattery, J.; Sandercock, P.A. Interobserver reliability of a clinical classification of acute cerebral infarction. Stroke J. Cereb. Circ. 1993, 24, 1801-1804. [CrossRef]

34. Ng, G.J.L.; Quek, A.M.L.; Cheung, C.; Arumugam, T.V.; Seet, R.C.S. Stroke biomarkers in clinical practice: A critical appraisal. Neurochem. Int. 2017, 107, 11-22. [CrossRef] [PubMed]

35. Simpkins, A.N.; Janowski, M.; Oz, H.S.; Roberts, J.; Bix, G.; Doré, S.; Stowe, A.M. Biomarker Application for Precision Medicine in Stroke. Transl. Stroke Res. 2019, 30, 46-59. [CrossRef] [PubMed]

36. Menosi Gualandro, D.; Twerenbold, R.; Boeddinghaus, J.; Nestelberger, T.; Puelacher, C.; Müller, C. Biomarkers in cardiovascular medicine: Towards precision medicine. Swiss Med Wkly. 2019, 149, W20125. [CrossRef] [PubMed]

37. Peplow, P.V.; Martinez, B.; Dambinova, S.A. Stroke Biomarkers; Springer: New York, NY, USA, 2020.

38. Kamtchum-Tatuene, J.; Jickling, G.C. Blood Biomarkers for Stroke Diagnosis and Management. Neuromol. Med. 2019, 21, 1-25. [CrossRef]

39. Sharp, F.; Jickling, G.C. Biomarkers for the Diagnosis of Lacunar Stroke. Google Patents WO2012121978A2, 13 September 2012.

40. Ford, B.D.; Ford, G. Biomarkers for Stroke. Google Patents US20120040858A1, 16 February 2012.

41. Augello, C.J.; Noll, J.M.; Distel, T.J.; Wainright, J.D.; Stout, C.E.; Ford, B.D. Identification of novel blood biomarker panels to detect ischemic stroke in patients and their responsiveness to therapeutic intervention. Brain Res. 2018, 1698, 161-169. [CrossRef] 
42. Makris, K.; Haliassos, A.; Chondrogianni, M.; Tsivgoulis, G. Blood biomarkers in ischemic stroke: Potential role and challenges in clinical practice and research. Crit. Rev. Clin. Lab. Sci. 2018, 55, 294-328. [CrossRef]

43. Ng, G.J.; Ng, M.Y.; Quek, A.M.; Seet, R.C. Resolving Difficult Case Scenarios by Incorporating Stroke Biomarkers in Clinical Decision-making. In Acute Brain Impairment; Incorporating Stroke: London, UK, 2017; pp. 289-314.

44. Misra, S.; Kumar, A.; Kumar, P.; Yadav, A.K.; Mohania, D.; Pandit, A.K.; Prasad, K.; Vibha, D. Blood-based protein biomarkers for stroke differentiation: A systematic review. Proteom. Clin. Appl. 2017, 11, 1700007. [CrossRef]

45. LaMont, J.; Mc Connell, I.; Fitzgerald, P. Biomarker-Based Methods and Biochips for Aiding the Diagnosis of Stroke. Google Patents CN104272112A, 7 January 2015.

46. Montaner, J.; Ramiro, L.; Simats, A.; Tiedt, S.; Makris, K.; Jickling, G.C.; Debette, S.; Sanchez, J.-C.; Bustamante, A. Multilevel omics for the discovery of biomarkers and therapeutic targets for stroke. Nat. Rev. Neurol. 2020, 16,1-18. [CrossRef]

47. Pawluk, H.; Woźniak, A.; Grześk, G.; Kołodziejska, R.; Kozakiewicz, M.; Kopkowska, E.; Grzechowiak, E.; Kozera, G. The Role of Selected Pro-Inflammatory Cytokines in Pathogenesis of Ischemic Stroke. Clin. Interv. Aging 2020, 15, 469. [CrossRef]

48. Liu, K.J.; Liu, W.; Timmins, G.; Pan, R. Blood Biomarker for Early Blood Brain Barrier Disruption in Ischemic Stroke. Google Patents US20140314737A1, 23 October 2014.

49. Gasiorek, P.; Banach, M.; Sakowicz, A.; Głąbiński, A.; Sosnowska, B.; Maciejewski, M.; Bielecka-Dabrowa, A. The potential role of inflammation in cryptogenic stroke. Adv. Med Sci. 2019, 64, 381-387. [CrossRef]

50. Harpaz, D.; Eltzov, E.; Seet, R.; Marks, R.S.; Tok, A.I.Y. Point-of-care-testing in acute stroke management: An unmet need ripe for technological harvest. Biosensors 2017, 7, 30. [CrossRef]

51. Monbailliu, T.; Goossens, J.; Hachimi-Idrissi, S.; Idigr, S.H. Blood protein biomarkers as diagnostic tool for ischemic stroke: A systematic review. Biomark. Med. 2017, 11, 503-512. [CrossRef]

52. Vemmos, K.N.; Spengos, K.; Tsivgoulis, G.; Zakopoulos, N.; Manios, E.; Kotsis, V.; Daffertshofer, M.; Vassilopoulos, D. Factors influencing acute blood pressure values in stroke subtypes. J. Hum. Hypertens. 2004, 18, 253-259. [CrossRef] [PubMed]

53. Jiang, J.; Jiang, Y.; Feng, S.; Sun, D.; Zhuang, A.; Zeng, Q.; Zhang, Y.; Huang, H.; Nie, H.; Zhou, F. Microembolic signal monitoring of TOAST-classified cerebral infarction patients. Mol. Med. Rep. 2013, 8, 1135-1142. [CrossRef]

54. Ohara, T.; Yamamoto, Y.; Nagakane, Y.; Tanaka, E.; Morii, F.; Koizumi, T. Classification of etiologic subtypes for transient ischemic attacks: Clinical significance of lacunar transient ischemic attack. Clin. Neurol. 2011, 51, 406. [CrossRef] [PubMed]

55. Saposnik, G.; Hassan, K.A.; Selchen, D.; Fang, J.; Kapral, M.K.; Smith, E.E. Stroke unit care: Does ischemic stroke subtype matter? Int. J. Stroke 2011, 6, 244-250. [CrossRef] [PubMed]

56. Kumar, M.A.; Vangala, H.; Tong, D.C.; Campbell, D.M.; Balgude, A.; Eyngorn, I.; Beraud, A.S.; Olivot, J.M.; Hsia, A.W.; Bernstein, R.A. MRI guides diagnostic approach for ischaemic stroke. J. Neurol. Neurosurg. Psychiatry 2011, 82, 1201-1205. [CrossRef] [PubMed]

57. Sonderer, J.; Katan Kahles, M. Aetiological blood biomarkers of ischaemic stroke. Swiss Med Wkly. 2015, 145, w14138. [CrossRef] [PubMed]

58. Katan, M.; Elkind, M.S.V. The potential role of blood biomarkers in patients with ischemic stroke: An expert opinion. Clin. Transl. Neurosci. 2018, 2, 2514183X18768050. [CrossRef]

59. Tian, D.; Yang, Q.; Dong, Q.; Li, N.; Yan, B.; Fan, D. Trends in stroke subtypes and vascular risk factors in a stroke center in China over 10 years. Sci. Rep. 2018, 8, 1-8. [CrossRef]

60. Jickling, G.C.; Sharp, F.R. Biomarker panels in ischemic stroke. Stroke J. Cereb. Circ. 2015, 46, 915-920. [CrossRef] [PubMed]

61. Chaudhuri, J.R.; Sharma, V.K.; Mridula, K.R.; Balaraju, B.; Bandaru, V.C. Association of plasma brain natriuretic peptide levels in acute ischemic stroke subtypes and outcome. J. Stroke Cerebrovasc. Dis. Off. J. Natl. Stroke Assoc. 2015, 24, 485-491. [CrossRef] [PubMed]

62. Cojocaru, I.M.; Cojocaru, M.; Sapira, V.; Ionescu, A.; Barlan, S.; Tacu, N. Could pro-BNP, uric acid, bilirubin, albumin and transferrin be used in making the distinction between stroke subtypes? Rom. J. Intern. Med. 2013, 51, 188-195. [CrossRef] [PubMed] 
63. Kawase, S.; Kowa, H.; Suto, Y.; Fukuda, H.; Kusumi, M.; Nakayasu, H.; Nakashima, K. Plasma Brain Natriuretic Peptide is a Marker of Prognostic Functional Outcome in Non-Cardioembolic Infarction. J. Stroke Cerebrovasc. Dis. Off. J. Natl. Stroke Assoc. 2015, 24, 2285-2290. [CrossRef]

64. Llombart, V.; Antolin-Fontes, A.; Bustamante, A.; Giralt, D.; Rost, N.S.; Furie, K.; Shibazaki, K.; Biteker, M.; Castillo, J.; Rodriguez-Yanez, M.; et al. B-type natriuretic peptides help in cardioembolic stroke diagnosis: Pooled data meta-analysis. Stroke J. Cereb. Circ. 2015, 46, 1187-1195. [CrossRef]

65. Wu, Z.; Zhao, M.; He, M.; Zeng, H.; Tan, F.; Li, K.; Chen, S.; Han, Q.; Wang, Q. Validation of the use of B-type natriuretic peptide point-of-care test platform in preliminary recognition of cardioembolic stroke patients in the ED. Am. J. Emerg. Med. 2015, 33, 521-526. [CrossRef]

66. Hajsadeghi, S.; Kashani Amin, L.; Bakhshandeh, H.; Rohani, M.; Azizian, A.R.; Jafarian Kerman, S.R. The diagnostic value of $\mathrm{N}$-terminal pro-brain natriuretic peptide in differentiating cardioembolic ischemic stroke. J. Stroke Cerebrovasc. Dis. Off. J. Natl. Stroke Assoc. 2013, 22, 554-560. [CrossRef]

67. Kara, K.; Gronewold, J.; Neumann, T.; Mahabadi, A.A.; Weimar, C.; Lehmann, N.; Berger, K.; Kalsch, H.I.; Bauer, M.; Broecker-Preuss, M.; et al. B-type natriuretic peptide predicts stroke of presumable cardioembolic origin in addition to coronary artery calcification. Eur. J. Neurol. 2014, 21, 914-921. [CrossRef]

68. Maruyama, K.; Shiga, T.; Iijima, M.; Moriya, S.; Mizuno, S.; Toi, S.; Arai, K.; Ashihara, K.; Abe, K.; Uchiyama, S. Brain natriuretic peptide in acute ischemic stroke. J. Stroke Cerebrovasc. Dis. Off. J. Natl. Stroke Assoc. 2014, 23, 967-972. [CrossRef]

69. Qihong, G.; Zhixin, W.; Mingfeng, H.; Lianhong, Y.; Wenchong, X. Experiences and the use of BNP POCT platform on suspected stroke patients by a Chinese emergency department. Ann. Indian Acad. Neurol. 2014, 17, 243-244.

70. Sakai, K.; Shibazaki, K.; Kimura, K.; Aoki, J.; Kobayashi, K.; Fujii, S.; Okada, Y. Brain natriuretic peptide as a predictor of cardioembolism in acute ischemic stroke patients: Brain natriuretic peptide stroke prospective study. Eur. Neurol. 2013, 69, 246-251. [CrossRef] [PubMed]

71. Shibazaki, K.; Kimura, K.; Iguchi, Y.; Okada, Y.; Inoue, T. Plasma brain natriuretic peptide can be a biological marker to distinguish cardioembolic stroke from other stroke types in acute ischemic stroke. Intern. Med. 2009, 48, 259-264. [CrossRef] [PubMed]

72. Mohamed, W.S.; ElGawad, E.A.A.; ElMotayam, A.S.; Fathy, S.E. Cardio embolic stroke and blood biomarkers: Diagnosis and predictors of short-term outcome. Egypt. J. Neurol. Psychiatry Neurosurg. 2019, 55, 68. [CrossRef]

73. Yang, H.-1.; Lin, Y.-P.; Long, Y.; Ma, Q.-1.; Zhou, C. Predicting Cardioembolic Stroke with the B-Type Natriuretic Peptide Test: A Systematic Review and Meta-analysis. J. Stroke Cerebrovasc. Dis. 2014, 23, 1882-1889. [CrossRef]

74. Wu, Z.; Yang, L.; Guo, Q.; He, M.; Li, K. Experiences and the use of BNP POCT platform on suspected ischemic stroke patients in the emergency department setting. Clin. Neurol. Neurosurg. 2014, 123, 199-200. [CrossRef]

75. Ueno, Y.; Tanaka, R.; Yamashiro, K.; Shimada, Y.; Kuroki, T.; Hira, K.; Urabe, T.; Hattori, N. Impact of BNP on cryptogenic stroke without potential embolic sources on transesophageal echocardiography. J. Neurol. Sci. 2015, 359, 287-292. [CrossRef]

76. Otaki, Y.; Watanabe, T.; Sato, N.; Shirata, T.; Tsuchiya, H.; Wanezaki, M.; Tamura, H.; Nishiyama, S.; Arimoto, T.; Takahashi, H. Direct comparison of prognostic ability of cardiac biomarkers for cardiogenic stroke and clinical outcome in patients with stroke. Heart Vessel. 2019, 34, 1178-1186. [CrossRef]

77. Bai, J.; Sun, H.; Xie, L.; Zhu, Y.; Feng, Y. Detection of cardioembolic stroke with B-type natriuretic peptide or N-terminal pro-BNP: A comparative diagnostic meta-analysis. Int. J. Neurosci. 2018, 128, 1100-1108. [CrossRef]

78. Lee, S.-J.; Lee, D.-G.; Lim, D.-S.; Hong, S.; Park, J.-S. Difference in the prognostic significance of N-terminal pro-B-type natriuretic peptide between cardioembolic and noncardioembolic ischemic strokes. Dis. Markers 2015, 2015, 597570. [CrossRef]

79. Nakamura, M.; Ishibashi, Y.; Tanaka, F.; Omama, S.; Onoda, T.; Takahashi, T.; Takahashi, S.; Tanno, K.; Ohsawa, M.; Sakata, K. Ability of B-Type Natriuretic Peptide Testing to Predict Cardioembolic Stroke in the General Population-Comparisons With C-Reactive Protein and Urinary Albumin. Circ. J. 2018, 82, 1017-1025. [CrossRef] 
80. Zhixin, W.U.; Yingying, L.I.; Liang, S.; Qing, F.; Lei, J.; Chen, J.; Mingfeng, H.E.; Kuangyi, L.I. The value of using B-type natriuretic peptide and D-dimer in preliminary recognition of cardioembolic stroke patients. J. Pract. Med. 2018, 34, 44-48.

81. Lee, S.-J.; Lee, D.-G.; Chung, T.-I. N-Terminal pro-B-Type Natriuretic Peptide Predicts Long-Term Mortality but not Stroke Recurrence in Acute Ischemic Stroke Patients with a Cardioembolic Source (P1. 051); AAN Enterprises: Haryana, India, 2015.

82. Hosomi, N.; Yoshimoto, T.; Kanaya, Y.; Neshige, S.; Hara, N.; Himeno, T.; Kono, R.; Takeshima, S.; Takamatsu, K.; Ota, T. Brain natriuretic peptide and particular left ventricle segment asynergy associated with cardioembolic stroke from old myocardial infarction. J. Stroke Cerebrovasc. Dis. 2016, 25, 1165-1171. [CrossRef] [PubMed]

83. Okada, Y.; Terakawa, Y.; Murata, T.; Nakamura, K.; Shimotake, K.; Murata, H.; Ohata, K. Ability of NT-pro-BNP to Diagnose Cardioembolic Etiology in Patients with Acute Ischemic Stroke. Osaka City Med. J. 2016, 62, 95-102.

84. Harpaz, D.; Seet, R.; Marks, R.S.; Tok, A.I.Y. B-Type Natriuretic Peptide as a Significant Brain Biomarker for Stroke Triaging Using a Bedside Point-of-Care Monitoring Biosensor. Biosensors 2020, 10, 107. [CrossRef]

85. Ageno, W.; Finazzi, S.; Steidl, L.; Biotti, M.G.; Mera, V.; Melzi D’Eril, G.; Venco, A. Plasma measurement of D-dimer levels for the early diagnosis of ischemic stroke subtypes. Arch. Intern. Med. 2002, 162, 2589-2593. [CrossRef] [PubMed]

86. Dougu, N.; Takashima, S.; Sasahara, E.; Taguchi, Y.; Toyoda, S.; Hirai, T.; Nozawa, T.; Tanaka, K.; Inoue, H. Differential diagnosis of cerebral infarction using an algorithm combining atrial fibrillation and D-dimer level. Eur. J. Neurol. 2008, 15, 295-300. [CrossRef] [PubMed]

87. Haapaniemi, E.; Tatlisumak, T. Is D-dimer helpful in evaluating stroke patients? A systematic review. Acta Neurol. Scand. 2009, 119, 141-150. [CrossRef]

88. Isenegger, J.; Meier, N.; Lammle, B.; Alberio, L.; Fischer, U.; Nedeltchev, K.; Gralla, J.; Kohler, H.P.; Mattle, H.P.; Arnold, M. D-dimers predict stroke subtype when assessed early. Cerebrovasc. Dis. 2010, 29, 82-86. [CrossRef]

89. Robson, S.C.; Shephard, E.G.; Kirsch, R.E. Fibrin degradation product D-dimer induces the synthesis and release of biologically active IL-1 beta, IL- 6 and plasminogen activator inhibitors from monocytes in vitro. Br. J. Haematol. 1994, 86, 322-326. [CrossRef]

90. Sato, T.; Sato, S.; Yamagami, H.; Komatsu, T.; Mizoguchi, T.; Yoshimoto, T.; Takagi, M.; Ihara, M.; Koga, M.; Iwata, H. D-dimer level and outcome of minor ischemic stroke with large vessel occlusion. J. Neurol. Sci. 2020, 413, 116814. [CrossRef]

91. Yuan, W.; Shi, Z.H. The relationship between plasma D-dimer levels and outcome of Chinese acute ischemic stroke patients in different stroke subtypes. J. Neural Transm. 2014, 121, 409-413. [CrossRef] [PubMed]

92. Zi, W.J.; Shuai, J. Plasma D-dimer levels are associated with stroke subtypes and infarction volume in patients with acute ischemic stroke. PLoS ONE 2014, 9, e86465. [CrossRef] [PubMed]

93. Hirano, K.; Takashima, S.; Dougu, N.; Taguchi, Y.; Nukui, T.; Konishi, H.; Toyoda, S.; Kitajima, I.; Tanaka, K. Study of hemostatic biomarkers in acute ischemic stroke by clinical subtype. J. Stroke Cerebrovasc. Dis. Off. J. Natl. Stroke Assoc. 2012, 21, 404-410. [CrossRef] [PubMed]

94. Takano, K.; Yamaguchi, T.; Uchida, K. Markers of a hypercoagulable state following acute ischemic stroke. Stroke J. Cereb. Circ. 1992, 23, 194-198. [CrossRef] [PubMed]

95. Melake, M.S.; El-Kabany, R.A.; Al-Emam, A.I.; El-Shereef, A.M.; Okda, M. The role of D-dimer, fibrinogen and C-reactive protein as plasma biomarkers in acute ischemic stroke. J. Neurol. Res. 2016, 5, 277-282. [CrossRef]

96. Liu, L.-B.; Li, M.; Zhuo, W.-Y.; Zhang, Y.-S.; Xu, A.-D. The role of hs-CRP, D-dimer and fibrinogen in differentiating etiological subtypes of ischemic stroke. PLoS ONE 2015, 10, e0118301. [CrossRef]

97. Alvarez-Perez, F.J.; Castelo-Branco, M.; Alvarez-Sabin, J. Albumin level and stroke. Potential association between lower albumin level and cardioembolic aetiology. Int. J. Neurosci. 2011, 121, 25-32. [CrossRef]

98. Bonaventura, A.; Liberale, L.; Vecchié, A.; Casula, M.; Carbone, F.; Dallegri, F.; Montecucco, F. Update on inflammatory biomarkers and treatments in ischemic stroke. Int. J. Mol. Sci. 2016, 17, 1967. [CrossRef]

99. Masotti, L.; Ceccarelli, E.; Forconi, S.; Cappelli, R. Prognostic role of C-reactive protein in very old patients with acute ischaemic stroke. J. Intern. Med. 2005, 258, 145-152. [CrossRef] 
100. Suwanwela, N.C.; Chutinet, A.; Phanthumchinda, K. Inflammatory markers and conventional atherosclerotic risk factors in acute ischemic stroke: Comparative study between vascular disease subtypes. J. Med Assoc. Thail. 2006, 89, 2021-2027.

101. Rana, D.S.; Anand, I.; Batra, A.; Sethi, P.K.; Bhargava, S. Serum levels of high-sensitivity C-reactive protein in acute ischemic stroke and its subtypes: A prospective case-control study. Asia Pac. J. Clin. Trials Nerv. Syst. Dis. 2018, 3, 128. [CrossRef]

102. Luo, Y.; Wang, Z.; Li, J.; Xu, Y. Serum CRP Concentrations and Severity of Ischemic Stroke Subtypes. Can. J. Neurol. Sci. J. Can. Sci. Neurol. 2012, 39, 69-73. [CrossRef] [PubMed]

103. Lehmann, M.F.; Kallaur, A.P.; Oliveira, S.R.; Alfieri, D.F.; Delongui, F.; de Sousa Parreira, J.; de Araújo, M.C.M.; Rossato, C.; de Almeida, J.T.; Pelegrino, L.M. Inflammatory and metabolic markers and short-time outcome in patients with acute ischemic stroke in relation to TOAST subtypes. Metab. Brain Dis. 2015, 30, 1417-1428. [CrossRef] [PubMed]

104. Ladenvall, C.; Jood, K.; Blomstrand, C.; Nilsson, S.; Jern, C.; Ladenvall, P. Serum C-reactive protein concentration and genotype in relation to ischemic stroke subtype. Stroke J. Cereb. Circ. 2006, 37, 2018-2023. [CrossRef]

105. Zeng, L.; He, X.; Liu, J.; Wang, L.; Weng, S.; Wang, Y.; Chen, S.; Yang, G.-Y. Differences of circulating inflammatory markers between large-and small vessel disease in patients with acute ischemic stroke. Int. J. Med. Sci. 2013, 10, 1399. [CrossRef]

106. Solovyeva, L.N.; Shmonin, A.A.; Emanuel, Y.V.; Stolyarov, M.S.; Bondareva, E.A.; Mazing, V.A.; Lazareva, N.M.; Kholopova, I.V.; Blinova, T.V.; Kharitonova, T.V. The clinical laboratory markers of atherosclerosis in patients with atherothrombotic stroke. Klin. Lab. Diagn. 2015, 60, 12-16.

107. Tuttolomondo, A.; Di Raimondo, D.; Pecoraro, R.; Arnao, V.; Pinto, A.; Licata, G. Inflammation in ischemic stroke subtypes. Curr. Pharm. Des. 2012, 18, 4289-4310. [CrossRef]

108. Licata, G.; Tuttolomondo, A.; Di Raimondo, D.; Corrao, S.; Di Sciacca, R.; Pinto, A. Immuno-inflammatory activation in acute cardio-embolic strokes in comparison with other subtypes of ischaemic stroke. Thromb. Haemost. 2009, 101, 929-937.

109. Piccardi, B.; Giralt, D.; Bustamante, A.; Llombart, V.; García-Berrocoso, T.; Inzitari, D.; Montaner, J. Blood markers of inflammation and endothelial dysfunction in cardioembolic stroke: Systematic review and meta-analysis. Biomarkers 2017, 22, 200-209. [CrossRef]

110. Gokhan, S.; Ozhasenekler, A.; Mansur Durgun, H.; Akil, E.; Ustundag, M.; Orak, M. Neutrophil lymphocyte ratios in stroke subtypes and transient ischemic attack. Eur. Rev. Med Pharmacol. Sci. 2013, 17, 653-657.

111. Elkind, M.S.; Sciacca, R.R.; Boden-Albala, B.; Rundek, T.; Paik, M.C.; Sacco, R.L. Relative elevation in baseline leukocyte count predicts first cerebral infarction. Neurology 2005, 64, 2121-2125. [CrossRef] [PubMed]

112. Guven, H.; Cilliler, A.E.; Sarikaya, S.A.; Koker, C. The Etiologic and Prognostic Importance of High Leukocyte and Neutrophil Counts in Acute Ischemic Stroke. J. Neurol. Sci. 2010, 27, 311-318.

113. Tokgoz, S.; Kayrak, M.; Akpinar, Z.; Seyithanoğlu, A.; Güney, F.; Yürüten, B. Neutrophil Lymphocyte Ratio as a Predictor of Stroke. J. Stroke Cerebrovasc. Dis. 2013, 22, 1169-1174. [CrossRef]

114. Domaç, F.; Ülker, M.; Karaci, R.; Demir, M. The Relation Between Neutrophil-Lymphocyte Ratio and Etiologic Subtypes in Acute Ischaemic Stroke. Med J. Haydarpaşa Numune Train. Res. Hosp. 2019. [CrossRef]

115. Lök, U.; Gülaçti, U. The predictive effect of the Neutrophil-to-Lymphocyte Ratio (NLR) on the mortality of acute ischemic stroke and its subtypes: A Retrospective Cross-Sectional Study. J. Acad. Emerg. Med. 2016, 15, 69.

116. Rodriguez-Yanez, M.; Castillo, J. Role of inflammatory markers in brain ischemia. Curr. Opin. Neurol. 2008, 21, 353-357. [CrossRef]

117. Iskra, T.; Turaj, W.; Slowik, A.; Szczudlik, A.; Dembinska-Kiec, A. Lipoprotein (a) in stroke patients with large and small vessel disease. Prz. Lek. 2002, 59, 877-880.

118. Bang, O.Y.; Saver, J.L.; Liebeskind, D.S.; Pineda, S.; Ovbiagele, B. Association of serum lipid indices with large artery atherosclerotic stroke. Neurology 2008, 70, 841-847. [CrossRef]

119. Laloux, P.; Galanti, L.; Jamart, J. Lipids in ischemic stroke subtypes. Acta Neurol. Belg. 2004, 104, 13-19.

120. Slowik, A.; Iskra, T.; Turaj, W.; Hartwich, J.; Dembinska-Kiec, A.; Szczudlik, A. LDL phenotype B and other lipid abnormalities in patients with large vessel disease and small vessel disease. J. Neurol. Sci. 2003, 214, 11-16. [CrossRef] 
121. Yuan, B.-B.; Luo, G.-G.; Gao, J.-X.; Qiao, J.; Yang, J.-B.; Huo, K.; Li, Y.-B.; Liu, Y. Variance of serum lipid levels in stroke subtypes. Clin. Lab. 2015, 61, 1509-1514. [CrossRef] [PubMed]

122. Cui, R.; Iso, H.; Yamagishi, K.; Saito, I.; Kokubo, Y.; Inoue, M.; Tsugane, S. High serum total cholesterol levels is a risk factor of ischemic stroke for general Japanese population: The JPHC study. Atherosclerosis 2012, 221, 565-569. [CrossRef] [PubMed]

123. Zambrelli, E.; Emanuele, E.; Marcheselli, S.; Montagna, L.; Geroldi, D.; Micieli, G. Apo(a) size in ischemic stroke: Relation with subtype and severity on hospital admission. Neurology 2005, 64, 1366-1370. [CrossRef] [PubMed]

124. Kim, B.S.; Jung, H.S.; Bang, O.Y.; Chung, C.S.; Lee, K.H.; Kim, G.M. Elevated serum lipoprotein(a) as a potential predictor for combined intracranial and extracranial artery stenosis in patients with ischemic stroke. Atherosclerosis 2010, 212, 682-688. [CrossRef]

125. Lee, N.S.; Daniels, L.B. Natriuretic Peptide Use in Screening in the Community. In Cardiac Biomarkers; Springer: Berlin, Germany,, 2016; pp. 181-193.

126. Balion, C.; McKelvie, R.; Don-Wauchope, A.C.; Santaguida, P.L.; Oremus, M.; Keshavarz, H.; Hill, S.A.; Booth, R.A.; Ali, U.; Brown, J.A. B-type natriuretic peptide-guided therapy: A systematic review. Heart Fail. Rev. 2014, 19, 553-564. [CrossRef]

127. Pemberton, C.J.; Charles, C.J.; Richards, A.M. Chapter 1-Cardiac Natriuretic Peptides. In Endocrinology of the Heart in Health and Disease; Schisler, J.C., Lang, C.H., Willis, M.S., Eds.; Academic Press: Cambridge, MA, USA, 2017; pp. 3-39.

128. Mair, J. Biochemistry of B-type natriuretic peptide-where are we now? Clin. Chem. Lab. Med. (CCLM) 2008, 46, 1507-1514. [CrossRef]

129. Atisha, D.; Bhalla, M.A.; Morrison, L.K.; Felicio, L.; Clopton, P.; Gardetto, N.; Kazanegra, R.; Chiu, A.; Maisel, A.S. A prospective study in search of an optimal B-natriuretic peptide level to screen patients for cardiac dysfunction. Am. Heart J. 2004, 148, 518-523. [CrossRef]

130. Tsioufis, C. Ischemic stroke in atrial fibrillation patients: Don't put the blame always on heart. Hell. J. Cardiol. 2018. [CrossRef]

131. Montaner, J.; Mendioroz, M.; Ribó, M.; Delgado, P.; Quintana, M.; Penalba, A.; Chacón, P.; Molina, C.; Fernández-Cadenas, I.; Rosell, A. A panel of biomarkers including caspase-3 and D-dimer may differentiate acute stroke from stroke-mimicking conditions in the emergency department. J. Intern. Med. 2011, 270, 166-174. [CrossRef]

132. Soomro, A.Y.; Guerchicoff, A.; Nichols, D.J.; Suleman, J.; Dangas, G.D. The current role and future prospects of D-dimer biomarker. Eur. Heart J. Cardiovasc. Pharmacother. 2016, 2, 175-184. [CrossRef]

133. Guo, Y.; Lip, G.Y.H.; Apostolakis, S. Inflammation in atrial fibrillation. J. Am. Coll. Cardiol. 2012, 60, 2263-2270. [CrossRef] [PubMed]

134. Wu, N.; Chen, X.; Cai, T.; Wu, L.; Xiang, Y.; Zhang, M.; Li, Y.; Song, Z.; Zhong, L. Association of inflammatory and hemostatic markers with stroke and thromboembolic events in atrial fibrillation: A systematic review and meta-analysis. Can. J. Cardiol. 2015, 31, 278-286. [CrossRef] [PubMed]

135. Tuttolomondo, A.; Di Raimondo, D.; Pecoraro, R.; Arnao, V.; Pinto, A.; Licata, G. Atherosclerosis as an inflammatory disease. Curr. Pharm. Des. 2012, 18, 4266-4288. [CrossRef] [PubMed]

136. Huang, G.; Zhong, X.N.; Zhong, B.; Chen, Y.Q.; Liu, Z.Z.; Su, L.; Ling, Z.Y.; Cao, H.; Yin, Y.H. Significance of white blood cell count and its subtypes in patients with acute coronary syndrome. Eur. J. Clin. Investig. 2009, 39, 348-358. [CrossRef] [PubMed]

137. Papa, A.; Emdin, M.; Passino, C.; Michelassi, C.; Battaglia, D.; Cocci, F. Predictive value of elevated neutrophil-lymphocyte ratio on cardiac mortality in patients with stable coronary artery disease. Clin. Chim. Acta Int. J. Clin. Chem. 2008, 395, 27-31. [CrossRef] [PubMed]

138. Cook, E.J.; Walsh, S.R.; Farooq, N.; Alberts, J.C.; Justin, T.A.; Keeling, N.J. Post-operative neutrophil-lymphocyte ratio predicts complications following colorectal surgery. Int. J. Surg. 2007, 5, 27-30. [CrossRef] [PubMed]

139. Caligiuri, G.; Nicoletti, A. Lymphocyte responses in acute coronary syndromes: Lack of regulation spawns deviant behaviour. Eur. Heart J. 2006, 27, 2485-2486. [CrossRef]

140. Karabinos, I.; Koulouris, S.; Kranidis, A.; Pastromas, S.; Exadaktylos, N.; Kalofoutis, A. Neutrophil count on admission predicts major in-hospital events in patients with a non-ST-segment elevation acute coronary syndrome. Clin. Cardiol. 2009, 32, 561-568. [CrossRef] 
141. Cummins, B.M.; Ligler, F.S.; Walker, G.M. Point-of-care diagnostics for niche applications. Biotechnol. Adv. 2016, 34, 161-176. [CrossRef]

142. Vasan, A.S.; Mahadeo, D.M.; Doraiswami, R.; Huang, Y.; Pecht, M. Point-of-care biosensor system. Front. Biosci. 2013, 5, 39-71. [CrossRef]

143. Yoo, E.H.; Lee, S.Y. Glucose biosensors: An overview of use in clinical practice. Sensors 2010, 10, 4558-4576. [CrossRef] [PubMed]

144. Shah, D.; Maghsoudlou, D. Enzyme-linked immunosorbent assay (ELISA): The basics. Br. J. Hosp. Med. 2016, 77, C98-C101. [CrossRef] [PubMed]

145. Price, C.P. Point of care testing. BMJ Br. Med J. 2001, 322, 1285-1288. [CrossRef]

146. Drain, P.K.; Hyle, E.P.; Noubary, F.; Freedberg, K.A.; Wilson, D.; Bishai, W.R.; Rodriguez, W.; Bassett, I.V. Diagnostic point-of-care tests in resource-limited settings. Lancet Infect. Dis. 2014, 14, 239-249. [CrossRef]

147. St John, A.; Price, C.P. Existing and Emerging Technologies for Point-of-Care Testing. Clin. Biochem. Rev. 2014, 35, 155-167. [PubMed]

148. Paul, S. Biomedical Engineering and its Applications in Healthcare; Springer: Berlin, Germany, 2019.

149. Harpaz, D.; Axelrod, T.; Yitian, A.L.; Eltzov, E.; Marks, R.S.; Tok, A.I.Y. Dissolvable polyvinyl-alcohol film, a time-barrier to modulate sample flow in a 3D-printed holder for capillary flow paper diagnostics. Materials 2019, 12, 343. [CrossRef]

150. Harpaz, D.; Eltzov, E.; Axelrod, T.; Marks, R.S.; Tok, A.I.Y. Membrane type comparison and modification to modulate sample flow in paper diagnostics. Biochem. Eng. J. 2020, 155, 107483. [CrossRef]

151. Harpaz, D.; Eltzov, E.; Ng, T.S.E.; Marks, R.S.; Tok, A.I.Y. Enhanced Colorimetric Signal for Accurate Signal Detection in Paper-Based Biosensors. Diagnostics 2020, 10, 28. [CrossRef]

152. Harpaz, D.; Koh, B.; Marks, R.S.; Seet, R.; Abdulhalim, I.; Tok, A.I.Y. Point-of-Care surface plasmon resonance biosensor for stroke biomarkers NT-proBNP and $S 100 \beta$ using a functionalized gold chip with specific antibody. Sensors 2019, 19, 2533. [CrossRef]

153. Harpaz, D.; Koh, B.; Seet, R.C.S.; Abdulhalim, I.; Tok, A.I.Y. Functionalized silicon dioxide self-referenced plasmonic chip as point-of-care biosensor for stroke biomarkers NT-proBNP and S100ß. Talanta 2020, 212, 120792. [CrossRef]

154. Sinawang, P.D.; Harpaz, D.; Fajs, L.; Seet, R.C.S.; Tok, A.I.Y.; Marks, R.S. Electrochemical impedimetric detection of stroke biomarker NT-proBNP using disposable screen-printed gold electrodes. EuroBiotech J. 2017, 1, 165-176. [CrossRef]

155. Kumar, S.; Kumar, S.; Ali, M.A.; Anand, P.; Agrawal, V.V.; John, R.; Maji, S.; Malhotra, B.D. Microfluidic-integrated biosensors: Prospects for point-of-care diagnostics. Biotechnol. J. 2013, 8, 1267-1279. [CrossRef] [PubMed]

156. Harpaz, D.; Eltzov, E.; Seet, R.C.S.; Marks, R.S.; Tok, A.I.Y. Rapid Point-of-Care-Tests for Stroke Monitoring. Org. Bioelectron. Life Sci. Healthc. 2019, 56, 263-314.

157. Drescher, M.J.; Spence, A.; Rockwell, D.; Smally, A.J. Point-of-Care Testing for Coagulation Studies in an Emergency Department Stroke Protocol: A Time-Saving Innovation. Ann. Emerg. Med. 2007, 50, S25. [CrossRef]

158. Eli, C.; Raviv, G.; Irene, N. Apparatus and Method to Determine Stroke Subtype. Google Patents WO/2016/077657, 19 May 2016.

159. Rizos, T.; Herweh, C.; Jenetzky, E.; Lichy, C.; Ringleb, P.A.; Hacke, W.; Veltkamp, R. Point-of-Care International Normalized Ratio Testing Accelerates Thrombolysis in Patients With Acute Ischemic Stroke Using Oral Anticoagulants. Stroke 2009, 40, 3547-3551. [CrossRef] [PubMed]

160. Walter, S.; Kostopoulos, P.; Haass, A.; Lesmeister, M.; Grasu, M.; Grunwald, I.; Keller, I.; Helwig, S.; Becker, C.; Geisel, J.; et al. Point-of-care laboratory halves door-to-therapy-decision time in acute stroke. Ann. Neurol. 2011, 69, 581-586. [CrossRef]

161. Adams, H.P., Jr.; del Zoppo, G.; Alberts, M.J.; Bhatt, D.L.; Brass, L.; Furlan, A.; Grubb, R.L.; Higashida, R.T.; Jauch, E.C.; Kidwell, C.; et al. Guidelines for the early management of adults with ischemic stroke: A guideline from the American Heart Association/American Stroke Association Stroke Council, Clinical Cardiology Council, Cardiovascular Radiology and Intervention Council, and the Atherosclerotic Peripheral Vascular Disease and Quality of Care Outcomes in Research Interdisciplinary Working Groups: The American Academy of Neurology affirms the value of this guideline as an educational tool for neurologists. Circulation 2007, 115, e478-e534. 
162. Karlinski, M.; Gluszkiewicz, M.; Czlonkowska, A. The accuracy of prehospital diagnosis of acute cerebrovascular accidents: An observational study. Arch. Med. Sci. 2015, 11, 530-535. [CrossRef]

163. Brandler, E.S.; Sharma, M.; Sinert, R.H.; Levine, S.R. Prehospital stroke scales in urban environments: A systematic review. Neurology 2014, 82, 2241-2249. [CrossRef]

164. Chen, X.; Wang, J.; Shan, Y.; Cai, W.; Liu, S.; Hu, M.; Liao, S.; Huang, X.; Zhang, B.; Wang, Y. Cerebral small vessel disease: Neuroimaging markers and clinical implication. J. Neurol. 2019, 266, 2347-2362. [CrossRef]

165. Regenhardt, R.W.; Das, A.S.; Lo, E.H.; Caplan, L.R. Advances in understanding the pathophysiology of lacunar stroke: A review. JAMA Neurol. 2018, 75, 1273-1281. [CrossRef] [PubMed]

C 2020 by the authors. Licensee MDPI, Basel, Switzerland. This article is an open access article distributed under the terms and conditions of the Creative Commons Attribution (CC BY) license (http://creativecommons.org/licenses/by/4.0/). 